\title{
Pseudoascites: unusual presentation of omental cyst
}

\author{
K. Gyves-Ray ${ }^{1}$, R.J.Hernandez ${ }^{1}$ and A.C. Hillemeier ${ }^{2}$ \\ The University of Michigan Hospitals, Departments of ${ }^{1}$ Radiology and \\ 2 Pediatrics and Communicable Diseases, Ann Arbor, Michigan, USA
}

Received: 5 February 1990; accepted: 19 March 1990

\begin{abstract}
An unusual case of omental cyst is described. The child initially presented with a unilocular intraperitoneal fluid collection on CT. After paracentesis, CT showed freely layering peritoneal fluid, with eventual complete resolution of fluid. CT eight months later demonstrated re-appearance of a multiseptated cystic mass. At surgery, an omental cyst was found.
\end{abstract}

\section{Case report}

A 26-month-old male was noted at routine examination to have a large, protuberant abdomen. The child's mother felt that the abdomen had always been large, and did not feel that there had been a sudden change in the abdominal girth. The physical examination was unremarkable, except for a soft, protuberant, non-tender abdomen.

AbdominalCTscan revealed a large collection of intraperitoneal fluid, extending from

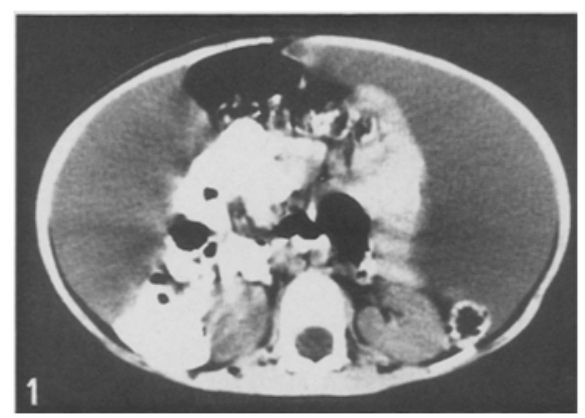

Fig.1. CT section through mid-abdomen demonstrates a large intraperitoneal fluid collection, which appears to displace bowel centrally. The fluid did not layer dependently in the pelvic cul-du-sac, and did not disperse around liver and spleen

Fig. 2. CT scan eight months later demonstrates development of a septated, loculated fluid collection occupying most of the mid-abdomen and pelvis

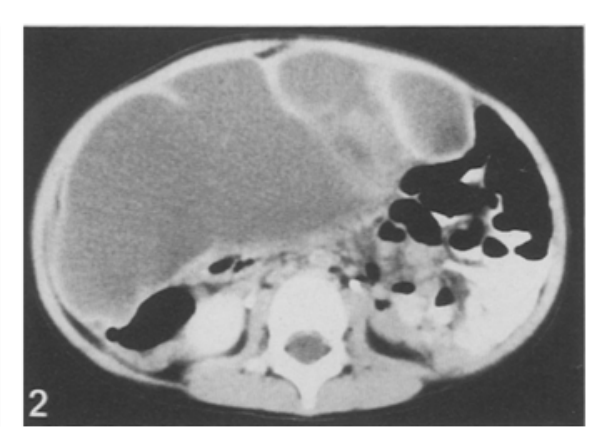

liver edge into the pelvis (Fig. 1). The fluid did not have imaging characteristics typical of ascites; specifically, the fluid did not layer dependently and did not disperse around the liver and spleen. There were no identifiable solid components or septations within the fluid collection. Subsequently, paracentesis was performed and revealed exudative fluid without microbial growth or neoplastic cells. Laboratory results were unremarkable.

Upon referral to our institution several weeks following paracentesis, a repeat abdominal CT scan revealed fluid collections in both paracolic gutters, significantly smaller than on the initial CT scan, which layered dependently in the prone position, indicating free intraperitoneal fluid. On the basis of these findings, a diagnosis of ascites was made. The child remained asymptomatic, and a follow-up CT scan two months later was normal with complete resolution of the peritoneal fluid. The child remained well until eight months later, when he presented with increasing abdominal distention. CT (Fig.2) and ultrasound performed at this time revealed reaccumulation of the fluid collection,

\section{Discussion}

The case reported here is of interest because it illustrates a distinctly unusual radiographic presentation of omental cyst, as well as several potential pitfalls in the radiologic diagnosis. The lesion initially appeared as a large, loculated fluid collection occupying a major portion of the peritoneal cavity. After paracentesis, the mass was decompressed, presumably through a small rent created by the paracentesis needle. The contents of the cyst were evacuated into the peritoneal cavity, explaining the appearance of freely layering ascites on the second CT scan. Subsequently, the cyst fluid was completely resorbed through the peritoneal lining, only to reaccumulate within a complex cystic mass as seen on the final CT scan and ultrasound. Thus, when the patient with a large mesenteric or omental cyst is imaged after paracentesis, a mistaken diagnosis of ascites might be made, and the origin of the peritoneal fluid from a cystic mass overlooked. In- 
deed, imaging after paracentesis may be normal if the cyst contents have been resorbed through the peritoneum.

Mesenteric and omental cysts are uncommon lesions which most often present as an enlarging, painless mass. When complicated by hemorrhage, infection, or torsion, they may be mistaken for acute appendicitis, Meckel's diverticulitis, or ovarian torsion [1]. Bowel obstruction or hydronephrosis may occur secondary to extrinsic compression of bowel or ureter by the mass. Malignant degeneration is rare, usually to a low grade sarcoma [2].

The typical imaging characteristics of mesenteric and omental cysts are those of a well defined, cystic mass exhibiting acoustic enhancement on ultrasound [3].
This was the initial appearance of the mass in our patient. Less commonly, these lesions may appear as complex, multiseptate cystic masses with variable solid components giving a "honeycomb" appearance on ultrasound [4]. This corresponds to the appearance of the mass in our patient after reaccumulation of fluid within the mass following paracentesis.

\section{References}

1. Gordon M, Sumner T (1975) Abdominal ultrasonography in a mesenteric cyst presenting as ascites. Gastroenterology 69 : 761
2. Hardin W, Hardy J (1970) Mesenteric cyst. Am J Surg 119:640

3. Wicks JD, Silver TM, Bree RL (1978) Giant cystic abdominal masses in children and adolescents: ultrasonic differential diagnosis. Am J Roentgenol 130: 853

4. Geer L, Mittelstadt C, Staab EV, Gaisie G (1984) Mesenteric cyst: sonographic appearance with CT correlation. Ped Radiol $14: 102$

K. Gyves-Ray, M.D.

Department of Radiology

Section of Pediatric Radiology

C.S. Mott Children's Hospital

University of Michigan Hospitals

1500 E. Medical Center Drive

Ann Arbor, Michigan 48109-0252

USA

Literature in pediatric radiology (continued from p.557)

\section{Röntgen-Bläfter (Stuttgart)}

Arachnoid cyst with complicating intracystic and subdural haemorrhage. Olsen, N.K., Madsen, H.H.T. (Arne Poulsensvej 7, 1.t.h., DK-7100 Vejle, Denmark) 43, $166(1990)$

CT appearances of an aneurysmal cyst of the spine in childhood. Hoeffel, J.C. et al. (Dept. of Rad., Children's Hosp., 5, Allée du Morwan, F-54511 Vandoeuvre-Les-Nancy Cédex, France) 43, 169 (1990)

Ultraschall in Klinik und Praxis (Berlin)

Ultrasound diagnosis of subcalvarial processes in infancy - comparison with CT. [In germ.] Kleinhans, F. et al. (Klinik für Kinderheilkunde der Med. Akademie, Emanuel-Larisch-Weg 17-19, DDR-3014 Magdeburg, GDR) 5,31(1990)

\section{Zeitschrift für Kinderchirurgie (Stuttgart)}

Brain stem dysfunction in Chiari II syndrome. [In germ.] Holschneider, A. et al. (Kinderchirurg. Klinik des Kinderkrankenhauses der Stadt, Amsterdamer Str.59, D-5000 Köln 60 (Riehl), FRG) 45, 67 (1990)

Innominate artery compression of the trachea in infancy - surgical therapy in 30 cases. [In germ.] Schuster, T. et al. (Hecker, W. C., Kinderchirurg. Klinik im Dr. von Haunerschen Kinderspital der Univ., Lindwurmstr. 4, D-8000 München 2, FRG) 45, 86 (1990)

Persistent subarachnoid pleural CSF fistula after extirpation of a thoracic ganglioneuroma. Case report. [In germ.] Trammer, A. (Kinderchirurg. Klinik im Dr. von Haunerschen Kinderspital der Univ., Lindwurmstr.4, D-8000 München 2, FRG) 45, 109 (1990)

Familial childhood achalasia. Senocak, M.E. et al. (Hacettepe Cocuk Hastanesi, Çocuk Cerrahisi Anabilim Dah, Ankara, Turkey) 45, 111 (1990)

Endodermal sinus tumour of the posteroinferior mediastinum resembling Dumbbell neuroblastoma in a child. Todani, T. et al. (Dept. of Paed. Surg., Med. School, 1750, Miki-Cho, Kita-Gun, Kagawa, 761-07 Japan) 45, 120 (1990)

International Journal of Pediatric Otorhinolaryngology (Amsterdam) Current management of choanal atresia. Morgan, D. W., Bailey, C. M. (Royal National Throat, Nose and Ear Hosp., London, WC1X 8DA, U.K.) 19, 1 (1990)

High resolution computed tomography of the temporal bone in infants and children: a review. Odrezin, G.T. et al. (The Children's Hosp., Dept. of Diagn. Imaging, 1600 7th Ave. South, Birmingham, AL 35233, USA) 19, 15 (1990)

Acta Radiologica (Stockholm)

Small bowel barium examination in children. Bååth, L. et al. (Dept. of Diagn Rad., Allmänna Sjukhus, S-21401 Malmö, Sweden) 30, 621 (1989)

Influence of urography on renal function in children. Stake, G. et al. (Dept. of Ped. Rad, Rikshosp., N-0027 Oslo 1, Norway) 30, 643 (1989)
Dynamic imaging of pulmonary ventilation in children using digital subtraction radiography. Svedström, E.J. et al. (Dept. of Rad., Univ. Central Hosp., SF-20520 Turku, Finland) 31, 53 (1990)

L'Otorinolaringologia Pediatrica (Rom)

Temporal localization of a case of histocytosis $\mathrm{X}$ in paediatric age. [In ital.] Vico. F. et al. (Univ. degli Studi di Torino, I Clinical Otoninolaringoiatrica, Italy) 1,29(1990)

Meditsinskaja Radiologiia (Moskva)

Thermographic and scintigraphic investigation of the soft tissues tumors in children. [In russ.] Khanagova, R. G. (Sci. Center of Oncol., of All-Russia, Acad. Med. Sci., Moskva, USSR) 35, 24 (1990)

\section{Pediatrija (Moskva)}

Estimation of the long-term results of endovascular occlusion of the open arterial canal by two-dimensional Doppler's echocardiography. [In russ.] Savelyev, S. V. et al. (Acad. Groups of Acad. Med. Sci., Inst. of Cardio-surg:; Moskva, USSR) 4, 74 (1990)

Ultrasonic diagnosis of the congenital abnormalities of brain development. [In russ.] Baerts, V. (Children's Clinic, Rotterdam, The Netherlands) 4, 78 (1990)

Radiologia Jugoslavica (Ljubljana)

Partial splenic embolization (PSE) in the treatment of portal hypertension with hypersplenism in childhood. [In jugosl.] Radanovic, B. et al (S. Gradica 13/2, YU-41020 Novi Zagreb, Yugoslavia) 24, 11 (1990)

Indian Journal of Radiology \& Imaging (Bombay)

Osteomyelitis in sickle cell disease. Ghosh, B.P., Samal, S. (Dept, of Rad., V.S. S. Med. College, BURLA-768 017, Dist. Sambalpur, Orissa, India) 44 $41(1990)$

Revista Cubana de Pediatria (La Habana)

Chylothorax: a propos of a case of a patient treated with intrapleural tetracycline. [In spaín] Reverôn, F.F. et al. (Hosp. Militar Central "Carlos J.Finlay", av. 41 y 114, Marianao, Habana 11500 , Cuba) 61443 (1989)

Panner's disease (osteochondritis of the humerus). Presentation of a case. [In spain] Puchades, A. P. et al. (Hosp. Ped., Calzada de San Miguel del Padrôn No. 1615, Guanabacoa, Ciudad de La Habana 11000, Cuba) 61, 586 (1989)

Adenomatoid malformation of the lung: report of three cases. [In spain] Mayor, I.F. et al. (Calle K No.151, ap. 3B entre 11 y 13, Vedado, Ciudad de La Habana, Cuba) 61, 711 (1989)

Congenital lobar emphysema. Presentation of three cases and review of the affection. [In spain] Cutting, J.M.R. et al. (Hosp. Infantil "Pedro Borrás Astorga", Calle F, entre 27 y 29, Vedado, La Habana, 10400, Cuba) 61, 719 (1989) 